\title{
Hymenobacter psychrotolerans sp. nov., isolated from the Qinghai-Tibet Plateau permafrost region
}

\author{
Correspondence \\ Huyuan Feng \\ fenghy@|zu.edu.cn \\ Lizhe An \\ lizhean@|zu.edu.cn
}

\author{
Gaosen Zhang, ${ }^{1,2}$ Fujun Niu, ${ }^{2}$ Hans-Jürgen Busse, ${ }^{3}$ Xiaojun $\mathrm{Ma},{ }^{1}$ \\ Wei Liu, ${ }^{1}$ Maoxing Dong, ${ }^{1}$ Huyuan Feng, ${ }^{1,2}$ Lizhe $\mathrm{An}^{1,2}$ \\ and Guodong Cheng ${ }^{2}$
}
${ }^{1}$ School of Life Sciences, Key Lab of Arid and Grassland Agroecology of MOE, Lanzhou University, Lanzhou 730000, PR China
${ }^{2}$ State Key Lab of Frozen Soil and Engineering, Cold and Arid Regions Environmental and Engineering Research Institute, CAS, Lanzhou 730000, PR China
${ }^{3}$ Institut für Bakteriologie, Mykologie und Hygiene, Veterinärmedizinische Universität Wien, A-1210 Vienna, Austria

\begin{abstract}
A psychrotolerant bacterium, designated strain Tibet-IIU $11^{\top}$, was isolated from the Qinghai-Tibet Plateau permafrost region, China. A taxonomic study was conducted using a polyphasic approach, with determination of physiological and biochemical properties and phylogenetic analysis based on 16S rRNA gene sequences. The novel isolate was found to belong to the genus Hymenobacter and was distinct from the recognized species of this genus. The major fatty acids were iso- $\mathrm{C}_{15: 0}(24.5 \%)$, summed feature $3\left(\mathrm{C}_{16: 1} \omega 7 \mathrm{c}\right.$ and/or iso $\left.\mathrm{C}_{15: 0} 2-\mathrm{OH} ; 20.0 \%\right)$, summed feature 4 (iso- $\mathrm{C}_{17: 1} \mathrm{I}$ and/or anteiso- $\left.\mathrm{C}_{17: 1} \mathrm{~B} ; 14.0 \%\right), \mathrm{C}_{16: 1} \omega 5 c(12.7 \%)$ and anteiso- $\mathrm{C}_{15: 0}(8.4 \%)$. Phosphatidylethanolamine and an unknown aminophospholipid were predominant in the polar lipid profile. The quinone system consisted exclusively of menaquinone MK-7 and sym-homospermidine was the major polyamine present. These chemotaxonomic traits are in good agreement with the characteristics of the genus Hymenobacter. The assignment of the novel isolate to this genus was further supported by a DNA G $+\mathrm{C}$ content of $60 \mathrm{~mol} \%$. On the basis of the polyphasic evidence presented in this study, it is proposed that strain Tibet-IIU $11^{\top}$ $\left(=\mathrm{DSM} 18569^{\mathrm{T}}=\mathrm{CGMCC} 1.6365^{\mathrm{T}}\right)$ represents a novel species, Hymenobacter psychrotolerans sp. nov.
\end{abstract}

The Qinghai-Tibet Plateau represents a unique and important permafrost environment, being a result of high elevation and low latitude caused by land uplift in the order of $3000 \mathrm{~m}$ over the last 2 million years (Wang \& French, 1995). Such a unique permafrost environment might accommodate an original microbial assemblage. In the course of a study on microbial diversity in the QinghaiTibet Plateau permafrost region (Zhang et al., 2007b), a bacterial strain, designated Tibet-IIU $11^{\mathrm{T}}$, was isolated and subjected to detailed characterization in order to clarify its taxonomic status.

Strain Tibet-IIU11 ${ }^{\mathrm{T}}$ was isolated from a permafrost sediment sample collected from the Beilu river basin $\left(34^{\circ} 50^{\prime} \mathrm{N} 92^{\circ} 56^{\prime} \mathrm{E}, 4676 \mathrm{~m}\right.$ above sea level) in the Qinghai-Tibet Plateau region of China, in August 2002 by

Abbreviations: SEM, scanning electron microscopy/micrograph; TEM, transmission electron microscopy/micrograph.

The GenBank/EMBL/DDBJ accession number for the 16S rRNA gene sequence of strain Tibet-IIU $11^{\top}$ is DQ177475. using the standard dilution plating technique. Isolation was achieved after incubation on PYGV (Staley, 1968) at $4{ }^{\circ} \mathrm{C}$ for 30 days. The isolate was routinely cultured with liquid R2A medium (Oxoid) and maintained as a glycerol suspension $(15 \%, \mathrm{w} / \mathrm{v})$ at $-80{ }^{\circ} \mathrm{C}$.

Genomic DNA was extracted and purified as described by Sambrook et al. (1989). The almost complete 16S rRNA gene (Escherichia coli positions 8-1510) of strain TibetIIU $11^{\mathrm{T}}$ was amplified and sequenced as described previously (Zhang et al., 2007a). The gene sequence of strain Tibet-IIU11 ${ }^{\mathrm{T}}$ was aligned (CLUSTAL W 1.81; Thompson et al., 1997) with the sequences of type strains of species exhibiting the highest sequence similarities as obtained from the Ribosomal Database Project (Cole et al., 2003) and the European Molecular Biology Laboratory (EMBL). Phylogenetic dendrograms were constructed by the neighbour-joining method (Saitou \& Nei, 1987) and tree topologies were evaluated by performing bootstrap analysis (Felsenstein, 1985) of 1000 resamplings by use of the MEGA2 package (Kumar et al., 2001). 
Preliminary sequence comparisons with 16S rRNA gene sequences held in GenBank indicated that the novel isolate was closely related to members of the genus Hymenobacter. Strain Tibet-IIU11 ${ }^{\mathrm{T}}$ showed the highest $16 \mathrm{~S}$ rRNA gene sequence similarity to Hymenobacter rigui $\mathrm{WPCB} 131^{\mathrm{T}}$ (96.6\%), Hymenobacter actinosclerus CCUG $39621^{\mathrm{T}}$ $(95.5 \%)$ and Hymenobacter gelipurpurascens $\operatorname{Txg}^{\mathrm{T}}$ (95.3\%); these values are well below the threshold generally accepted for the delineation of bacterial species (Stackebrandt \& Goebel, 1994). The 16S rRNA gene sequence similarities of strain Tibet-IIU $11^{\mathrm{T}}$ to those of Hymenobacter xinjiangensis $\mathrm{X} 2-1 \mathrm{~g}^{\mathrm{T}}$, Hymenobacter aerophilus I/26-Cor $1^{\mathrm{T}}$, Hymenobacter chitinivorans $\mathrm{Txcl}^{\mathrm{T}}$, Hymenobacter norwichensis $\mathrm{NS} / 50^{\mathrm{T}}$, Hymenobacter ocellatus Myx $2105^{\mathrm{T}}$ and Hymenobacter roseosalivarius AA- $718^{\mathrm{T}}$ were 95.0, 93.9, 94.9, 94.2, 90.5 and $93.4 \%$, respectively, values that were within the range found among the recognized species of the genus (Buczolits et al., 2006). The relationship of strain Tibet-IIU11 ${ }^{\mathrm{T}}$ to the other species of the genus Hymenobacter was also evident from its position in the phylogenetic tree. Strain Tibet-IIU $11^{\mathrm{T}}$ formed a robust clade together with $H$. gelipurpurascens $\operatorname{Txg} 1^{\mathrm{T}}, H$. xinjiangensis $\mathrm{X} 2-1 \mathrm{~g}^{\mathrm{T}}$ and $H$. rigui $\mathrm{WPCB} 131^{\mathrm{T}}$ in the neighbour-joining tree (Fig. 1). These results suggest that strain Tibet-IIU $11^{\mathrm{T}}$ represents a novel species within the genus Hymenobacter.

Growth on various standard bacteriological media was tested using tryptone soy agar (TSA), MacConkey agar, Czapek-Dox agar and R2A agar (Oxoid). Cells grown on $\mathrm{R} 2 \mathrm{~A}$ agar at $18{ }^{\circ} \mathrm{C}$ for $2-5$ days were used for physiological and biochemical tests. Cell motility was examined by phase-contrast microscopy using wet mounts. Cell morphology was observed under a transmission electron microscope (TEM) (JEM-1230; JEOL) by negative staining. For scanning electron microscopy (SEM), a bacterial sample was dehydrated with a graded series of acetone, critical point-dried with $\mathrm{CO}_{2}$ and sputter-coated with gold before examination (JSM-6380; JEOL). Gram behaviour was determined by the $\mathrm{KOH}$-lysis test (Moaledj, 1986) and by staining as described by Smibert \& Krieg (1994). Cell sizes were estimated using an Olympus BX-60 microscope by DAPI staining according to Porter \& Feig (1990), as modified by Sherr et al. (1992), from cells grown in R2A at $18{ }^{\circ} \mathrm{C}$ for $72 \mathrm{~h}$. Conventional biochemical tests were performed as described by Smibert \& Krieg (1994), including tests for oxidase, catalase, nitrate reduction, $\mathrm{H}_{2} \mathrm{~S}$ production, citrate utilization, indole production and urease activity. Carbon-source utilization tests and qualitative enzyme tests were performed with microtitre plates as described previously (Kämpfer et al., 1991). Antimicrobial susceptibility testing was conducted as described by Buczolits et al. (2002). Growth at various $\mathrm{pH}$ values ( $\mathrm{pH} 4$ to 12 ) was analysed by modifying the $\mathrm{pH}$ of R2A medium. Optical densities at $540 \mathrm{~nm}$ were monitored after growing cells in a shaker at $20{ }^{\circ} \mathrm{C}$ for $24 \mathrm{~h}$. The temperature range for growth was tested between 4 to $37{ }^{\circ} \mathrm{C}$ using $\mathrm{R} 2 \mathrm{~A}$ agar. The effect of $\mathrm{NaCl}$ on growth was tested by supplementing R2A medium with $0.5,1,2,3$ and $5 \%(\mathrm{w} / \mathrm{v}) \mathrm{NaCl}$ and incubating for 1 week at $20{ }^{\circ} \mathrm{C}$. Enzyme activities were tested using the API ZYM kit (bioMérieux) following the manufacturer's instructions. Detailed results are shown in Table 1 and are given in the species description. It is evident from Table 1 that there are at least five physiological characteristics that readily differentiate strain Tibet-IIU $11^{\mathrm{T}}$ from other species of the genus Hymenobacter.

Cells grown on R2A agar were collected for whole cellular fatty acid analysis. Cellular fatty acids of strain TibetIIU $11^{\mathrm{T}}$ were analysed as methyl esters by GLC according to the instructions of the Microbial Identification System (MIDI). The $\mathrm{G}+\mathrm{C}$ content of the DNA was determined according to the thermal denaturation method (Marmur \& Doty, 1962) on a UV spectrophotometer (UV-1700 PharmaSpec; Shimadzu). Strain Tibet-IIU11 ${ }^{\mathrm{T}}$ contained a complex fatty acid profile consisting of predominantly branched fatty acids with minor amounts of straight-chain fatty acids (Table 2). Most of the fatty acids that are characteristic of other Hymenobacter species (Hirsch et al., 1998; Buczolits et al., 2002, 2006; Baik et al., 2006; Zhang et al., 2007c) were detected, but differences in the quantities present were useful for differentiation of the species (Table 2). The DNA G $+\mathrm{C}$ content of strain TibetIIU $11^{\mathrm{T}}$ was $60 \mathrm{~mol} \%$.

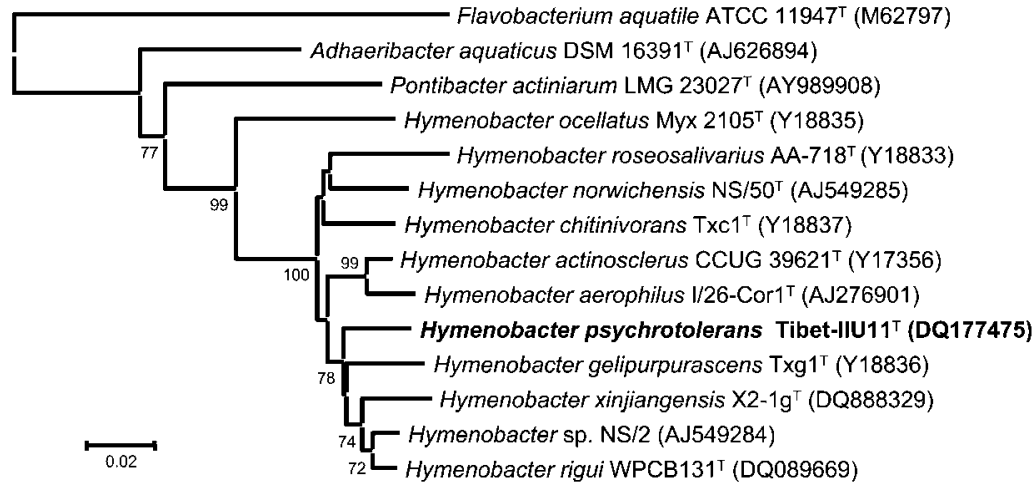

Fig. 1. Neighbour-joining phylogenetic tree based on nearly complete 16S rRNA gene sequences showing the relationships between strain Tibet-IIU11 ${ }^{\top}$ and related taxa within the phylum Bacteroidetes. The numbers at the nodes indicate the percentages of bootstrap sampling derived from 1000 replications. The sequence of Flavobacterium aquatile ATCC $11947^{\top}$ (M62797) was used as an outgroup. Bar, 2 inferred nucleotide substitutions per 100 nucleotides. 
Table 1. Characteristics that distinguish strain Tibet-IIU $11^{\top}$ from the type strains of other species of the genus $H y m e n o b a c t e r$

Strains: 1, Tibet-IIU11 ${ }^{\mathrm{T}}$ (this study); 2, H. roseosalivarius DSM $11622^{\mathrm{T}}$ (Hirsch et al., 1998); 3, H. actinosclerus CCUG $39621^{\mathrm{T}}$ (Collins et al., 2000); 4, H. aerophilus DSM $13606^{\mathrm{T}}$ (Buczolits et al., 2002); 5, H. rigui WPCB131 ${ }^{\mathrm{T}}$ (Baik et al. 2006); 6, H. chitinivorans Txc1 $^{\mathrm{T}}$; 7 , H. gelipurpurascens $\mathrm{Txg}^{\mathrm{T}}$; 8, H. ocellatus Myx 2105 ${ }^{\mathrm{T}}$; 9, H. norwichensis NS/50 ${ }^{\mathrm{T}}$ (Buczolits et al., 2006); 10, H. xinjiangensis X2-1g ${ }^{\mathrm{T}}$ (Zhang et al., 2007c). +, Positive; $(+)$, weakly positive; - , negative; ND, not determined; pNA, $p$-nitrophenyl; pNP, $p$-nitroanilide. All strains are negative for assimilation of Lrhamnose and maltitol but no results were reported for $H$. xinjiangensis $\mathrm{X} 2-1 \mathrm{~g}^{\mathrm{T}}$.

\begin{tabular}{|c|c|c|c|c|c|c|c|c|c|c|}
\hline Characteristic & 1 & 2 & 3 & 4 & 5 & 6 & 7 & 8 & 9 & 10 \\
\hline \multicolumn{11}{|l|}{ Growth at/in: } \\
\hline $4{ }^{\circ} \mathrm{C}$ & + & + & - & + & + & + & $(+)$ & - & $(+)$ & + \\
\hline $37^{\circ} \mathrm{C}$ & - & - & + & - & + & - & - & + & - & $(+)$ \\
\hline $1 \% \mathrm{NaCl}$ & + & + & $\mathrm{ND}$ & + & + & $(+)$ & $(+)$ & + & - & - \\
\hline $3 \% \mathrm{NaCl}$ & - & $\mathrm{ND}$ & $\mathrm{ND}$ & $(+)$ & - & $(+)$ & $(+)$ & + & - & - \\
\hline$N$-Acetyl-D-glucosamine, gluconate & - & - & $(+)$ & - & - & - & - & - & - & $(+)$ \\
\hline p-Arbutin, D-ribose & - & - & $(+)$ & - & - & - & - & - & $(+)$ & - \\
\hline D-Cellobiose & - & - & $(+)$ & - & + & - & - & - & $(+)$ & + \\
\hline D-Xylose & - & - & - & + & - & - & - & - & $(+)$ & $\mathrm{ND}$ \\
\hline D-Glucose & + & - & $(+)$ & $(+)$ & + & - & - & - & $(+)$ & - \\
\hline D-Mannose & + & - & $(+)$ & $(+)$ & - & - & - & - & $(+)$ & $(+)$ \\
\hline Propionate & $(+)$ & $(+)$ & $(+)$ & $(+)$ & - & - & - & - & - & + \\
\hline Glutarate & - & $(+)$ & $(+)$ & - & - & - & - & - & - & - \\
\hline Pyruvate & - & $(+)$ & $(+)$ & - & - & - & - & - & - & - \\
\hline $\begin{array}{l}\text { cis-Aconitate, adipate, citrate, fumarate, DL-3-hydroxybutyrate, L-malate, } \\
\text { itaconate, DL-lactate, mesaconate, oxoglutarate, suberate, L-alanine, L-proline, } \\
\text { L-phenylalanine }\end{array}$ & - & - & $(+)$ & - & - & - & - & - & - & - \\
\hline \multicolumn{11}{|l|}{ Hydrolysis of: } \\
\hline pNP $\beta$-D-glucuronide & - & - & - & - & ND & - & - & + & - & $\mathrm{ND}$ \\
\hline pNP phosphate, pNP $\alpha$-D-glucopyranoside, L-proline pNA & $(+)$ & $(+)$ & $(+)$ & $(+)$ & ND & - & + & + & $(+)$ & ND \\
\hline pNP $\beta$-D-glucopyranoside & - & - & - & - & ND & - & - & + & $(+)$ & ND \\
\hline bis-pNP phosphate & $(+)$ & $(+)$ & $(+)$ & $(+)$ & $\mathrm{ND}$ & - & - & + & $(+)$ & ND \\
\hline
\end{tabular}

Growth conditions for production of biomass and the techniques for the extraction and analyses of the polyamines, quinone system and polar lipids were all as reported previously (Busse \& Auling, 1988; Tindall, 1990a, b; Altenburger et al., 1996; Stolz et al., 2007). The polyamine pattern of strain Tibet-IIU $11^{\mathrm{T}}$ contained mainly sym-homospermidine $\left(2.0 \mu \mathrm{mol} \mathrm{g}^{-1}\right.$ dry weight $)$ and minor amounts of putrescine $\left(0.3 \mu \mathrm{mol} \mathrm{g}^{-1}\right.$ dry weight $)$, spermidine $\left(0.3 \mu \mathrm{mol} \mathrm{g}^{-1}\right.$ dry weight $)$ and spermine $\left(0.1 \mu \mathrm{mol} \mathrm{g}^{-1}\right.$ dry weight $)$. The main quinone was menaquinone-7 (MK-7). The polar lipid profile (Fig. 2) consisted mainly of phosphatidylethanolamine (PE) and an unknown aminophospholipid (APL3). Two unknown polar lipids (L1 and L2) occurred at moderate levels. Three unidentified aminophospholipids (APL1, 2, 4) and an unknown aminolipid (AL1) were also present. The majority of the chemotaxonomic characteristics were in good agreement with those reported for other species of the genus Hymenobacter (Buczolits et al., 2002, 2006), but the polar lipid profile contained some compounds that may be useful for the differentiation of the novel strain from other species of the genus.

The results of phylogenetic investigations, as well as major chemotaxonomic characteristics, demonstrate that strain Tibet-IIU $11^{\mathrm{T}}$ is a member of the genus Hymenobacter. However, the complete polar lipid profile and the relative amounts of certain fatty acids, as well as several physiological characteristics, clearly distinguish this new isolate from other recognized species of the genus Hymenobacter (Tables 1 and 2). Therefore, it is concluded that strain Tibet-IIU $11^{\mathrm{T}}$ should be classified as a novel species within the genus Hymenobacter, for which the name Hymenobacter psychrotolerans sp. nov. is proposed. 
Table 2. Relative amounts (\%) of fatty acids of strain Tibet-IIU $11^{\top}$ and the type strains of species of the genus Hymenobacter

Strains: 1, Tibet-IIU11 ${ }^{\mathrm{T}}$ (this study); 2, H. roseosalivarius DSM $11622^{\mathrm{T}}$ (Hirsch et al., 1998); 3, H. actinosclerus CCUG $39621^{\mathrm{T}}$ (Collins et al., 2000); 4, H. aerophilus DSM $13606^{\mathrm{T}}$ (Buczolits et al., 2002); 5, H. rigui WPCB131 ${ }^{\mathrm{T}}$ (Baik et al., 2006); 6, H. chitinivorans Txc1 ${ }^{\mathrm{T}}$; 7, H. gelipurpurascens $\mathrm{Txg}^{\mathrm{T}}$; 8, H. ocellatus Myx 2105 ${ }^{\mathrm{T}}$; 9, H. norwichensis NS $/ 50^{\mathrm{T}}$ (Buczolits et al., 2006); 10, H. xinjiangensis X2-1g ${ }^{\mathrm{T}}$ (Zhang et al., 2007c). Values are relative percentages of total fatty acids. Strain Tibet-IIU $11^{\mathrm{T}}$ was grown on R2A agar at $18{ }^{\circ} \mathrm{C}$ for $48 \mathrm{~h}$ prior to analysis. For unsaturated fatty acids, the position of the double bond can be located by counting from the methyl $(\omega)$ end of the carbon chain; cis isomers are indicated by the suffix $c$. Summed features represent groups of two or three fatty acids that could not be separated by GLC with the MIDI system. Summed features: 1, iso$\mathrm{C}_{15: 1} \mathrm{I}$ and/or $\mathrm{C}_{13: 0} 3-\mathrm{OH} ; 3, \mathrm{C}_{16: 1} \omega 7 c$ and/or iso- $\mathrm{C}_{15: 0}$ 2-OH; 4, iso- $\mathrm{C}_{17: 1} \mathrm{I}$ and/or anteiso- $\mathrm{C}_{17: 1} \mathrm{~B}$.

\begin{tabular}{|c|c|c|c|c|c|c|c|c|c|c|}
\hline Fatty acid & 1 & 2 & 3 & 4 & 5 & 6 & 7 & 8 & 9 & 10 \\
\hline iso- $\mathrm{C}_{13: 0}$ & - & - & - & - & - & 0.6 & - & 0.6 & - & - \\
\hline $\mathrm{C}_{14: 0}$ & 0.8 & - & - & - & - & - & - & - & 1.3 & 1.3 \\
\hline Unknown 16.535 & 0.6 & - & - & - & - & 0.5 & 0.8 & - & - & - \\
\hline iso- $\mathrm{C}_{14: 0}$ & - & - & - & - & - & 0.5 & - & 1.5 & 0.8 & - \\
\hline iso- $\mathrm{C}_{15: 1} \mathrm{G}$ & 1.8 & - & - & - & - & 0.6 & 0.8 & - & - & 2.0 \\
\hline anteiso- $\mathrm{C}_{15: 1} \mathrm{~A}$ & 0.6 & - & - & - & - & - & 1.1 & - & - & - \\
\hline Summed feature 1 & 1.5 & - & 2.3 & 0.8 & - & 2.1 & - & 2.7 & 0.8 & 2.2 \\
\hline iso- $\mathrm{C}_{15: 0}$ & 24.5 & 8.3 & 22.3 & 10.8 & 34.8 & 31.1 & 17.3 & 36.7 & 27.3 & 19.5 \\
\hline anteiso- $\mathrm{C}_{15: 0}$ & 8.4 & - & 25.8 & 22.3 & 5.9 & 3.7 & 23.1 & 3.9 & 10.6 & 3.7 \\
\hline iso- $\mathrm{C}_{15: 0} 3-\mathrm{OH}$ & 2.7 & 2.7 & 1.6 & 1.6 & - & 4.1 & 2.3 & 4.3 & 2.2 & 2.2 \\
\hline $\mathrm{C}_{15: 0} 2-\mathrm{OH}$ & - & - & 0.8 & 0.9 & - & - & 0.9 & - & - & - \\
\hline $\mathrm{C}_{15: 1} \omega 6 c$ & 0.6 & - & 0.8 & 0.8 & - & - & - & - & 0.5 & - \\
\hline $\mathrm{C}_{15: 0}$ & - & - & - & - & - & - & - & - & 0.5 & - \\
\hline iso- $\mathrm{C}_{16: 1} \mathrm{H}$ & 1.2 & 2.7 & 1.5 & 1.5 & - & 2.0 & 3.7 & 1.3 & 1.4 & 1.8 \\
\hline $\mathrm{C}_{16: 1} \omega 7 c$ alcohol & - & 0.7 & - & - & - & - & - & - & - & - \\
\hline iso- $\mathrm{C}_{16: 0} 3-\mathrm{OH}$ & - & 1.0 & - & - & - & - & - & - & - & - \\
\hline $\mathrm{C}_{16: 1} \omega 5 c$ & 12.7 & 23.3 & 3.7 & 7.9 & 15.0 & 8.9 & 11.3 & 2.0 & 13.6 & 10.6 \\
\hline Summed feature 3 & 20.0 & 29.8 & 13.1 & 21.4 & 13.8 & 13.9 & 17.6 & 5.4 & 23.6 & 20.2 \\
\hline iso- $\mathrm{C}_{16: 0}$ & 2.1 & 2.1 & - & 0.8 & - & 1.4 & 2.7 & 2.9 & 1.2 & 1.0 \\
\hline $\mathrm{C}_{16: 0}$ & 2.3 & 1.1 & - & 1.7 & 6.4 & - & - & 0.6 & 2.2 & 6.2 \\
\hline $\mathrm{C}_{16: 0} 3-\mathrm{OH}$ & 1.4 & 1.2 & - & - & - & 0.5 & - & - & 0.6 & - \\
\hline iso- $\mathrm{C}_{17: 0}$ & 0.4 & 1.7 & 1.8 & 4.5 & 5.0 & 2.6 & 1.7 & 2.8 & 1.6 & 1.8 \\
\hline anteiso- $\mathrm{C}_{17: 0}$ & - & - & 0.7 & 2.3 & - & - & 2.0 & - & - & $<1$ \\
\hline iso- $\mathrm{C}_{17: 0} 3-\mathrm{OH}$ & 3.5 & 5.8 & 3.1 & 3.5 & 3.1 & 6.2 & 3.7 & 6.8 & 3.0 & 3.4 \\
\hline $\mathrm{C}_{17: 0} 2-\mathrm{OH}$ & - & - & 2.0 & 1.3 & - & - & 1.7 & - & - & - \\
\hline$C_{17: 1} \omega 6 c$ & - & 1.1 & 0.7 & - & - & - & - & 1.2 & - & - \\
\hline iso- $\mathrm{C}_{17: 1} \omega 9 c$ & - & - & - & - & - & 0.7 & - & 0.6 & - & - \\
\hline Summed feature 4 & 14.0 & 18.5 & 19.9 & 17.7 & 14.4 & 20.8 & 9.4 & 26.9 & 8.3 & 8.5 \\
\hline
\end{tabular}

\section{Description of Hymenobacter psychrotolerans sp. nov.}

Hymenobacter psychrotolerans (psy.chro.to'ler.ans. Gr. adj. psychros cold; L. part. adj. tolerans tolerating; N.L. adj. psychrotolerans tolerating cold temperature).

Cells are rod-shaped (Fig. 3), aerobic, non-spore-forming and produce water-insoluble light pink pigment. Cells are approximately $0.8-1.7 \times 0.5 \mu \mathrm{m}$. Motility is not observed. Colonies on R2A agar are translucent, low-convex, circular, smooth and slimy; diameter is up to $4.0 \mathrm{~mm}$ after 5 days at $18-20{ }^{\circ} \mathrm{C}(\mathrm{pH} 7)$. Growth occurs in $0-1.5 \%(\mathrm{w} / \mathrm{v}) \mathrm{NaCl}$ (optimum $0 \%$ ), pH 5-10 (optimum pH 7) and at $4-28{ }^{\circ} \mathrm{C}$ (optimum $18{ }^{\circ} \mathrm{C}$ ). Cells are Gram-negative according to Gram-staining and the $\mathrm{KOH}(3 \%)$ test. Growth occurs on TSA and R2A agar, but not on Czapek-Dox agar or MacConkey agar. Oxidase- and catalase-positive. Nitrate reduction is positive without production of gas. Negative for production of indole from tryptophan, arginine dihydrolase or urease. Positive in the API ZYM system for alkaline phosphatase, esterase C4, esterase lipase C8, leucine arylamidase, cystine arylamidase, acid phosphatase, naphthol-AS-BIphosphohydrolase and valine arylamidase; negative for lipase $\mathrm{C} 14$, trypsin, chymotrypsin, $\beta$-galactosidase, $\beta$-glucuronidase, $\alpha$-glucosidase, $\beta$-glucosidase, $N$-acetyl- $\beta$-glucosaminidase, $\alpha$-galactosidase, $\alpha$-mannosidase and $\alpha$-fucosidase. Other characteristics are listed in Table 1. Sensitive to bacitracin (10 U), chloramphenicol (30 mg), colistin sulphate (10 mg), erythromycin (15 mg), fusidic acid (10 mg), gentamicin (10 mg), kanamycin (30 mg), penicillin G (10 U), vancomycin $(30 \mathrm{mg})$, polymyxin B sulphate $(300 \mathrm{U})$ and tetracycline $(10 \mathrm{mg})$. The fatty acid profile contains predominantly methyl-branched acids of the iso- and anteisotypes. The complete fatty acid profile is given in Table 2 . 


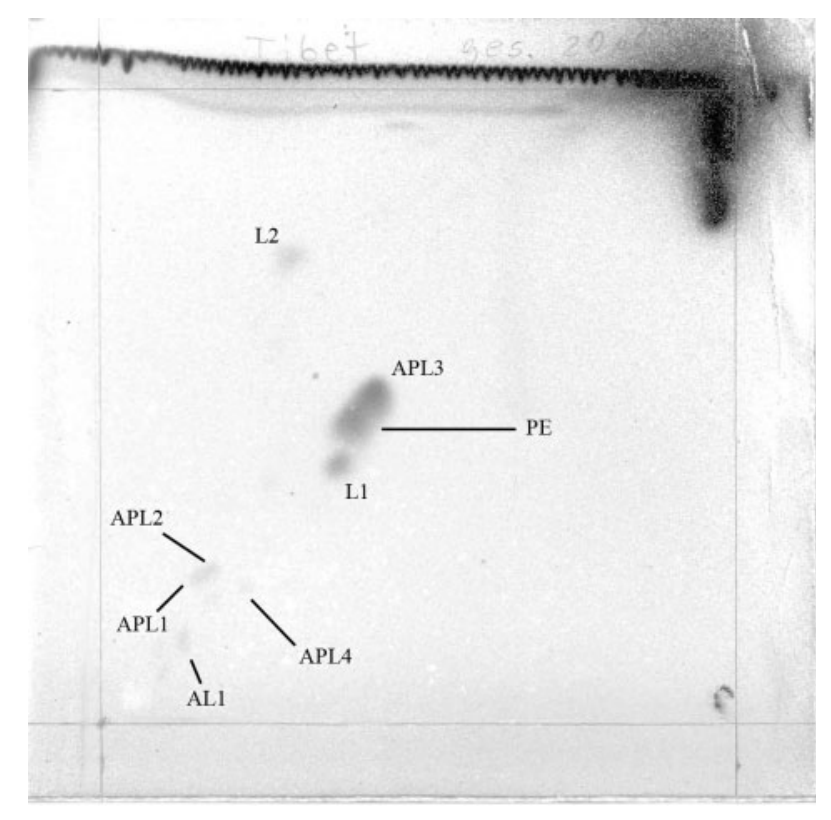

Fig. 2. Polar lipid profile of strain Tibet-IIU $11^{\top}$ after separation in two-dimensional TLC. APL1-4, unknown aminophospholipids 14; AL1, unknown aminolipid; L1, L2, unknown polar lipids.

The type strain, Tibet-IIU11 ${ }^{\mathrm{T}}\left(=\mathrm{DSM} 18569^{\mathrm{T}}=\mathrm{CGMCC}\right.$ $\left.1.6365^{\mathrm{T}}\right)$, was isolated from a permafrost sediment sample, Beilu river basin $\left(34^{\circ} 50^{\prime} \mathrm{N} 92^{\circ} 56^{\prime} \mathrm{E}, 4676 \mathrm{~m}\right.$ above sea level) in the Qinghai-Tibet Plateau, China. The DNA $\mathrm{G}+\mathrm{C}$ content of strain Tibet-IIU $11^{\mathrm{T}}$ is $60 \mathrm{~mol} \%$.

\section{Acknowledgements}

This work was funded by NSFC (J0630966, 30570270, 40471023, 30770329), by Program for New Century Excellent Talents in University (NCET) and the National Infrastructure of Natural Resources for Science and Technology (2005DKA21403). The authors wish to thank Hai Yang and Jun He for their help.

\section{References}

Altenburger, P., Kämpfer, P., Makristathis, A., Lubitz, W. \& Busse, H.-J. (1996). Classification of bacteria isolated from a medieval wall painting. J Biotechnol 47, 39-52.

Baik, K. S., Seong, C. N., Moon, E. Y., Park, Y.-D., Yi, H. \& Chun, J. (2006). Hymenobacter rigui sp. nov., isolated from wetland freshwater. Int J Syst Evol Microbiol 56, 2189-2192.

Buczolits, S., Denner, E. B. M., Kämpfer, P. \& Busse, H.-J. (2006). Proposal of Hymenobacter norwichensis sp. nov., classification of 'Taxeobacter ocellatus', 'Taxeobacter gelupurpurascens' and 'Taxeobacter chitinovorans' in the genus Hymenobacter as Hymenobacter ocellatus sp. nov., Hymenobacter gelipurpurascens sp. nov. and Hymenobacter chitinivorans sp. nov., respectively, and emended description of the genus Hymenobacter Hirsch et al. 1999. Int J Syst Evol Microbiol 56, 2071-2078.

Buczolits, S., Denner, E. B. M., Vybiral, D., Wieser, M., Kämpfer, P. \& Busse, H.-J. (2002). Classification of three airborne bacteria and
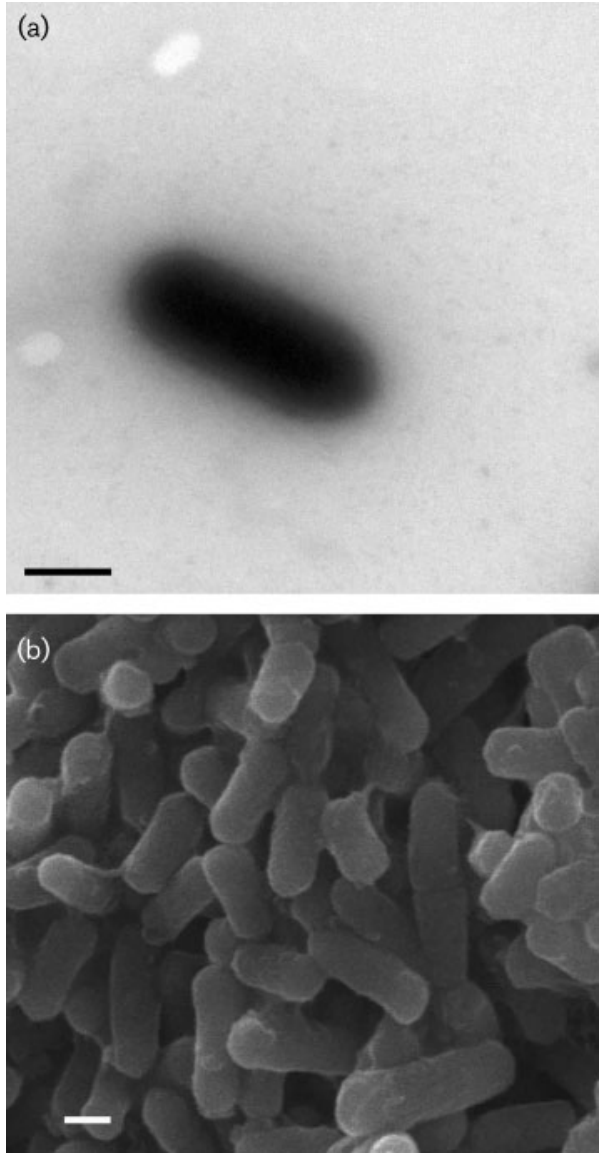

Fig. 3. TEM (a) and SEM (b) images of cells of strain Tibet-IIU11 ${ }^{\top}$. Bars, $0.5 \mu \mathrm{m}$.

proposal of Hymenobacter aerophilus sp. nov. Int J Syst Evol Microbiol 52, 445-456.

Busse, H. J. \& Auling, G. (1988). Polyamine pattern as a chemotaxonomic marker within the Proteobacteria. Syst Appl Microbiol 11, 1-8.

Cole, J. R., Chai, B., Marsh, T. L., Farris, R. J., Wang, Q., Kulam, S. A., Chandra, S., McGarrell, D. M., Schmidt, T. M. \& other authors (2003). The Ribosomal Database Project (RDP-II): previewing a new autoaligner that allows regular updates and the new prokaryotic taxonomy. Nucleic Acids Res 31, 442-443.

Collins, M. D., Hutson, R. A., Grant, I. R. \& Patterson, M. F. (2000). Phylogenetic characterization of a novel radiation-resistant bacterium from irradiated pork: description of Hymenobacter actinosclerus sp. nov. Int J Syst Evol Microbiol 50, 731-734.

Felsenstein, J. (1985). Confidence limits on phylogenies: an approach using the bootstrap. Evolution 39, 783-791.

Hirsch, P., Ludwig, W., Hethke, C., Sittig, M., Hoffmann, B. \& Gallikowski, C. A. (1998). Hymenobacter roseosalivarius gen. nov., sp. nov. from continental Antarctic soils and sandstone: bacteria of Cytophaga/Flavobacterium/Bacteroides line of phylogenetic descent. Syst Appl Microbiol 21, 374-383.

Kämpfer, P., Steiof, M. \& Dott, W. (1991). Microbiological characterization of a fuel-oil contaminated site including numerical 
identification of heterotrophic water and soil bacteria. Microb Ecol 21, 227-251.

Kumar, S., Tamura, K., Jakobsen, I. B. \& Nei, M. (2001). MEGA2: molecular evolutionary genetics analysis software. Bioinformatics 17, 1244-1245.

Marmur, J. \& Doty, P. (1962). Determination of the base composition of deoxyribonucleic acid from its thermal denaturation temperature. J Mol Biol 5, 109-118.

Moaledj, K. (1986). Comparison of Gram-staining and alternate methods, $\mathrm{KOH}$ test and aminopeptidase activity in aquatic bacteria: their application to numerical taxonomy. J Microbiol Methods 5, 303-310.

Porter, K. \& Feig, Y. S. (1990). The use of DAPI for identifying and counting aquatic microflora. Limnol Oceanogr 25, 943-948.

Saitou, N. \& Nei, M. (1987). The neighbor-joining method: a new method for reconstructing phylogenetic trees. Mol Biol Evol 4, 406-425.

Sambrook, J., Frisch, E. F. \& Maniatis, T. (1989). Molecular Cloning: a Laboratory Manual, 2nd edn. Cold Spring Harbor, NY: Cold Spring Harbor Laboratory.

Sherr, B. F., Sherr, E. B. \& McDaniel, J. (1992). Effect of protistan grazing on the frequency of dividing cells in bacterioplankton assemblages. Appl Environ Microbiol 58, 2381-2385.

Smibert, R. M. \& Krieg, N. R. (1994). Phenotypic characterisation. In Methods for General and Molecular Bacteriology, pp. 607-654. Edited by P. Gerhardt, R. G. E. Murray, W. A. Woods \& N. R. Krieg. Washington, DC: American Society for Microbiology.

Stackebrandt, E. \& Goebel, B. M. (1994). Taxonomic note: a place for DNA-DNA reassociation and $16 \mathrm{~S}$ rRNA sequence analysis in the present species definition in bacteriology. Int J Syst Bacteriol 44, 846-849.

Staley, J. T. (1968). Prosthecomicrobium and Ancalomicrobium: new prosthecate freshwater bacteria. J Bacteriol 95, 1921-1942.

Stolz, A., Busse, H.-J. \& Kämpfer, P. (2007). Pseudomonas knackmussii sp. nov. Int J Syst Evol Microbiol 57, 572-576.

Thompson, J. D., Gibson, T. J., Plewniak, F., Jeanmougin, F. \& Higgins, D. G. (1997). The CLUSTAL_X windows interface: flexible strategies for multiple sequence alignment aided by quality analysis tools. Nucleic Acids Res 25, 4876-4882.

Tindall, B. J. (1990a). Lipid composition of Halobacterium lacusprofundi. FEMS Microbiol Lett 66, 199-202.

Tindall, B. J. (1990b). A comparative study of the lipid composition of Halobacterium saccharovorum from various sources. Syst Appl Microbiol 13, 128-130.

Wang, B. \& French, H. M. (1995). Permafrost on the Tibet Plateau, China. Quatern Sci Rev 14, 255-274.

Zhang, G., Ma, X., Niu, F., Dong, M., Feng, H., An, L. \& Cheng, G. (2007a). Diversity and distribution of alkaliphilic psychrotolerant bacteria in the Qinghai-Tibet Plateau permafrost region. Extremophiles 11, 415-424.

Zhang, G., Niu, F., Ma, X., Liu, W., Dong, M., Feng, H., An, L. \& Cheng, G. (2007b). Phylogenetic diversity of bacteria isolates from the QinghaiTibet Plateau permafrost region. Can J Microbiol 53, 1000-1010.

Zhang, Q., Liu, C., Tang, Y., Zhou, G., Shen, P., Fang, C. \& Yokota, A. (2007c). Hymenobacter xinjiangensis sp. nov., a radiation-resistant bacterium isolated from the desert of Xinjiang, China. Int J Syst Evol Microbiol 57, 1752-1756. 